\title{
7 \\ Economic Equity and Major Development
}

\author{
Natalie Stoeckl
}

\section{Introduction}

It does not matter whether one looks at labour income, non-labour income or different measures of income/wealth concentration, inequality has been increasing within and across many countries throughout the last few decades (Jaumotte et al., 2013). Australia is no exception. On some measures, Australia is more unequal than the majority of other OECD countries (specifically, the gap between the poorest and the richest 10 per cent of households) and regional inequality has also risen sharply in recent times (Rodriguez-Pose, 2012). Most notable has been the rise in the share of total income that has gone to the richest 1 per cent of Australians; in 1980, the richest 1 per cent received just 5 per cent of all income, but by 2008 the richest 1 per cent were receiving almost 12 per cent of income-the fourth highest of all OECD countries (Hoeller et al., 2012). Thus, despite Australia's progressive tax system and targeted cash transfers, which seek to redistribute incomes, its above-average wage dispersion and large share of part-time/casual workers (Watson, 2013) mean that household disposable incomes are unevenly distributed and are becoming even more unequal over time (Hoeller et al., 2012).

This recent increase in inequality is likely to have surprised earlier generations of economists, primarily because Kuznets (1955) observed that, in the United States, England and Germany, increases in inequality 
occurred during the early periods of urbanisation and industrialisation, but inequality fell once each country reached a certain level of prosperity. Yet, despite the fact that early empirical tests were largely supportive of the Kuznets hypothesis in a variety of different contexts (Ahluwalia, 1976; Papanek \& Kyn, 1986; Campano \& Salvatore, 1988), more recent studies have not found evidence of diminishing inequality beyond a given income level (e.g. Anand \& Kanbur, 1993; Deininger \& Squire, 1998). Recent research indicates that, contrary to the Kuznets hypothesis (which presumes that inequality is determined by economic growth), inequality and growth are jointly determined and dependent on preferences and choices of economic agents (Cheng, 2006; Yang \& Zhang, 2003). The policy implication is that one cannot simply aim for economic growth hoping that inequality will (eventually) look after itself. If one cares about inequality (for any reason), one may need to take a more nuanced look at growth and development.

After discussing some of the costs of inequality (thus, establishing the need to consider it), this chapter briefly reviews literature that seeks to understand its causes, noting that inequality is often exacerbated by growth of high-tech industries, which increase the demand for (and wages of) skilled workers. It discusses that problem in the context of the Northern Australia development agenda, which has, among other foci, the goal of promoting growth by facilitating the development of large-scale (often high-tech) projects within the agribusiness, mining and energy sectors and, thus, may unintentionally serve to widen the gap between rich and poor in this region. It then proposes processes that would ameliorate the rising inequality likely to accompany such developments, suggesting ways in which those projects could become more financially connected to the communities within which they operate.

\section{The Cost of Inequality}

Arguably, there appears to be more public concern with economic growth than with equality; compare the number of times, for example, that the media reports on (growth of) GDP versus the number of times the media reports on the gap between rich and poor. This is despite the fact that a wide body of research, going back as far as Pigou in the 1920s, has suggested that it is not just the amount of money one earns that is important, but the amount one earns when compared to other people. Feelings about the importance of fairness are commonplace (Fehr \& 
Schmidt, 1999; Dawes et al., 2007)—not just among humans but among monkeys (Brosnan \& de Waal, 2003) and other animals. As such, failure to address inequity may generate social unrest (Wilkinson, 1996). Even those who do not feel that fairness is an important goal by and of itself may have good cause to worry about excessive concentration of wealth, since inequality has been linked to numerous social ills, including but not limited to crime, violence, drug abuse and large prison populations (Wilkinson, 1996; Wilkinson \& Pickett, 2010). Inequality has also been linked to school bullying (Elgar et al., 2013) and, in developing countries, to poor health outcomes (Leigh et al., 2009). Prisons, lawyers, police officers and security guards and health services are not free, so inequality imposes costs on society (Detotto \& Otranto, 2010; Cohen, 2012), often indirectly by placing pressure on government budgets.

Moreover, marginalised groups lack resilience and/or adaptive capacity and often live in regions (e.g. floodplains) that are particularly vulnerable to external shocks such as floods (Brouwer et al., 2009). These groups may require more government assistance to facilitate recuperation to unexpected shocks than less marginalised groups (Jaumotte et al., 2013), placing further strain on government budgets. Further, inequality of outcome is often associated with inequality of opportunity, which has long-term ramifications. It has been argued, for example, that low-income families are not be able to afford the same quality of education for their children as high-income families (Bailey \& Dynarski, 2011; Duncan \& Murnane, 2014). As such, today's unequal outcomes will contribute to tomorrow's unequal opportunities. This limits the growth potential of entire economies since not all members are able to fully contribute to or exploit emerging opportunities (Jaumotte et al., 2013).

Inequality is particularly profound in Northern Australia (Taylor et al., 2011). On one hand, it is the location of numerous mines with incomeadvantaged workers (Baum, 2006). But on the other, it is also home to some of the country's most disadvantaged people (as shown in the Australian Bureau of Statistics SEIFA indices) and many of the country's children most at risk of social exclusion (Tanton et al., 2009). Indeed, at least one-quarter of Australia's northern population belongs to the country's most socioeconomically disadvantaged and vulnerable group of people-Aboriginal and Torres Strait Islanders (Carson et al., 2009). Many of these Indigenous people live in abject poverty (Hunter, 1999), despite concerted policy attempts to 'close the gap'-a policy goal that many feel is largely unachievable within the near future (see, for example, Taylor $\&$ 
Hunter, 1998; Hunter \& Gray, 1999; Altman et al., 2008; Altman, 2009; Pholi et al., 2009). And the costs of that poverty are evident. There are, for example, significant differences in the life expectancy of Indigenous and non-Indigenous people (AIHW, 2010). There are also significant opportunity costs associated with this inequality; Taylor and Stanley (2005) estimate that the opportunity cost of poverty in just one remote Aboriginal settlement in Northern Territory likely exceeds A $\$ 40$ million per annum (measured as the value of foregone production).

In short, inequality imposes costs on society. If policymakers are able to choose between two different development proposals, it is clear that (all else equal) they should choose that which does most to redress inequality. This requires a more nuanced understanding of the link between economic growth and equality, a topic to which the next section turns.

\section{Causal Links between Economic Growth and Inequality}

Decades of work by researchers using various simple and numerous highly sophisticated techniques to analyse firm-level and country-level data has shed much light on and raised many questions about the causes of inequality, of which there are many. There is evidence to suggest, for example, that decentralisation may increase regional disparities (Ezcurra \& Rodriguez-Pose, 2013). Trade is thought to increase regional inequalities in low-middle-income countries that are strongly integrated with the rest of the world, but trade has, in other circumstances, been associated with reduced inequality (Rodriguez-Pose, 2012; Jaumotte et al., 2013). Globalisation is also believed to have an important role to play-off-shoring workers is a practice that tends to marginalise workers who perform routine tasks, multinational firms tend to employ more high-income earners than national firms and trade-induced innovation impacts relative wages (Harrison et al., 2010).

Considering all factors, the balance of research has suggested that recent worldwide increases in inequality are most significantly attributable to advances in technology (Jaumotte et al., 2013; Rodriguez-Pose, 2012). Evidently, it is growth of high-tech industries that is most likely to be associated with rising inequality. Formally, technology is believed to affect inequality because technological developments increase the demand for 
(and thus the incomes of) skilled workers much more than the demand for (and incomes of) unskilled workers. More recently, researchers have considered three groups of workers (low, middle and highly skilled) in more sophisticated models (Acemoglu \& Autor, 2010), but agree that technological progress favours the highly skilled (Jaumotte et al., 2013; Rodriguez-Pose, 2012). Thus, growth that is led by technology is frequently accompanied by rising labour market inequalities.

In remote areas across Northern Australia, skilled workers are often imported from other areas. For example, most local government areas within the Northern Territory import more workers than they export (Blackwell et al., 2015) and Brokensha et al. (2013) reported that 4.5 per cent of the Northern Territory's (NT) workforce and 23 per cent of the NT's mining workforce (a high-tech industry in this part of the world) were 'fly-in fly-out', 'drive-in drive-out' or 'bus-in bus-out' employees. Crucially, highly skilled imported workers do not always add to total employment. In their case study of the health industry in Tennant Creek, Carson and Carson (2014, p. 347) reported that the highly mobile medical professional part of the workforce did not just supplement a resident workforce, it completely replaced it'.

Other researchers have reported net income leakages from across the remote north, particularly from regions in which mining companies operate (Blackwell et al., 2015). Inequalities are also evident within mining regions. Reeson et al. (2012), for example, compared mining activity with measures of income inequality for both males and females in 728 Australian regions. They found evidence to support the Kuznets hypothesis for males (i.e. low inequality with no mining, moderate inequality with some mining and low inequality with high levels of mining), but for females, increases in mining activity were everywhere associated with increases in inequality. Reeson et al. (2012) argued that these marked differences were linked to the labour market-males are more likely to be employed in mining or associated industries than females and, thus, are in a better position to be able to capture either direct or indirect benefits from industrial expansion.

Having no way of earning money locally (be it through the sale of labour, hire of land and equipment or the sale of other goods and services) is also what seems to drive the marked inequities that exist between Indigenous and non-Indigenous people in Northern Australia (Stoeckl, Esparon et al., 2013). Far fewer Indigenous people are employed within the private 
sector or are the owner/operator of private businesses than would be expected on a per-capita basis (Stoeckl et al., 2007; Biddle et al., 2008). So, when regional developments occur, far fewer Indigenous people are able to benefit (directly or indirectly) from those developments than nonIndigenous people.

Other individuals who are not financially connected to the rest of the economy may also reap few benefits from regional development. Simply put, if segments of society are precluded from working or owning businesses, ${ }^{1}$ they will not be able to sell labour, goods or services to new developments or projects (either directly, or indirectly by participating further down the supply chain). Thus, they have no means of benefiting, financially, from the projects. So, unless development projects provide other (public) goods or services that benefit society as a whole (e.g. roads, ports, schools and hospitals) they will not benefit the marginalised.

Moreover, financially marginalised groups (those who reap few benefits from development) may also have external costs imposed on them, perhaps manifested as higher housing prices (Rolfe et al., 2007) or reduced environmental services (Stoeckl, Jackson et al., 2013). As such, it is possible that some within the community will incur net financial benefit from new developments while others will unambiguously lose. This issue likely explains at least some of the community backlash and discontent associated with new development proposals in regional Queensland. Rolfe et al. (2010) found that the indirect (flow-on) benefits associated with the mining-industry ${ }^{2}$ were higher in Brisbane (where mining does not occur) than in the regional areas (where the impacts of mining are felt).

The key point to be made here is that unless one can find ways of forging strong financial connections between broad sectors of the community, large-scale development projects (particularly those involving new or advanced technology) may exacerbate regional inequalities, imposing hidden costs on the wider community. Methods for doing so are discussed in the next section.

1 This seems to be the case for Aboriginal people in particular (Biddle et al., 2008), be it because of discrimination or otherwise. Options for redressing such issues are discussed in the next section.

2 Formally, the multipliers. 


\section{Key Policy Directions}

There has been much attention focused on strategies for promoting economic growth in Australia's north (Liberal Party of Australia, 2013), not just for the benefit of the region but the country as a whole. Some of these strategies seek to determine how to encourage and facilitate the establishment of large-scale agribusiness, mining and resource projects (Australian Government, 2015) such as the gas pipeline between Tennant Creek and Mount Isa (ABC News, 2015) and the Adani coal mine in Queensland.

If these large-scale projects are assessed and implemented as isolated enclaves (Faal, 2007), the growth that they generate may be uneconomic (Daly \& Farley, 2004) in that the costs of achieving such growth (including those associated with increased inequality) may exceed the benefits. To ensure that growth is genuinely economic (rather than uneconomic), projects should not just be selected on individual merit and should not just be subjected to the usual factors included in environmental or social impact assessments. They should also be assessed on their ability to reduce inequalities (or, at the very least, not to exacerbate them) by forging strong financial links with existing residents and businesses of Northern Australia.

This suggests a primary need to use metrics that enable one to assess the extent to which large-scale projects connect, financially, to the local economy (see Stoeckl, 2007, for one example). Such metrics should be used in conjunction with other information when assessing the desirability, or otherwise, of project proposals. They could also be used in long-term monitoring programs, perhaps setting targets for increased financial connectivity over time.

Supporting policies that could be put in place to help meet those targets include, but are not limited to:

- Implementing institutional reforms, particularly those relating to the ownership of core assets such as land and water. This is extremely important for Indigenous people, since ownership facilitates income (e.g. by charging other people rent to use the asset or by using it to produce money earning goods and services). The importance of reform is recognised as an important priority in documents related to northern development (Australian Government, 2015). 
- Devising community consultation processes (prior to projects being approved) that are specifically designed to identify opportunities for local residents and businesses to forge financial connections with project proponents. ${ }^{3}$ There will clearly be some goods (e.g. high technology pieces of capital equipment) that will need to be sourced from outside the region, but there are numerous other ways in which members of the community might connect to large-scale businesses. For example, one could consider options for supplying the food or running the dining hall for businesses that house workers on site in remote locations (which would be a relatively large business in a remote area; before ceasing operations, Century Zinc employed more than 750 people and the proposed Adani coal mine in Queensland could increase the local workforce by approximately $\left.1,400^{4}\right)$.

- Related to the above, one could devise programs that support the development of small businesses that supply goods and services to large-scale projects. A large percentage of first-time businesses that are operating in less economically challenging environments than Northern Australia (e.g. in urban areas) fail during their first year of operation (up to 70 per cent, see Shane, 2009). Moreover, research indicates that education levels, and access to finance are highly correlated with business outcomes (Doms et al., 2010). So, simply encouraging people to start small businesses, particularly people who are at socioeconomic disadvantage, without providing long-term training and support may be all but dooming them to fail. Instead, one needs to develop long-term programs that might initially involve training, education and work experience, but that would evolve over time, culminating in the situation where participants took over management and then ownership of businesses that supply the goods and/or services to the large-scale developments. For example, if seeking to help develop locally owned and managed businesses that supply food for miners, one could, in the first instance, provide training programs focused on local food production (e.g. establishment of market gardens). The programs could evolve to focus on issues related to quality control, packaging and transport, and then evolve once more to include business/financial training. This would, in essence, build the foundations for a local (food-related) business. Once operating confidently, further support

3 Current processes relating to Environmental Impact Assessments require community consultation, but do not require proponents to consider these issues.

4 Exact numbers are difficult to ascertain. See Campbell (2015). 
could be given to those associated with that business, helping them, for example, to source food (which cannot be grown locally) from elsewhere in Australia and, ultimately, taking over the food supply part of the mining operation.

- Enacting positive discrimination policies for large-scale projects specifically designed to favour local or marginalised employees or suppliers. One could, for example, require that project proponents ensure that a certain percentage of employees come from (locally) marginalised groups. Or one could require that a given per cent of project expenditure is undertaken with local businesses. Care must be taken to ensure that such measures do not create long-term incentives for economically inefficient behaviours (see Fryer \& Loury, 2005, for a good overview), but if enacted appropriately could prove to be an effective means of ensuring that even marginalised groups reap benefits from northern development.

\section{Concluding Comments}

The historical philosophy derived from the Kuznets hypothesis- that there is no need to worry about inequality since economic growth will, in the end, redress inequality—has been subsumed by a growing realisation that economic growth often exacerbates inequality. Likewise, the historical focus on literature assuming a trade-off between growth and equality (such as that considering the inefficiencies of taxation ${ }^{5}$ ) has been subsumed by body of evidence that growth and equality are not mutually exclusive (Koske et al., 2012). We now know that economic growth does not guarantee equality and that it will, instead, often exacerbate inequality. We also know that inequality imposes costs on society, the policy implication being that failure to consider inequality when assessing the desirability or otherwise of development proposals may mean that Northern Australian growth is uneconomic.

The exciting corollary to this realisation is that economic developments that help reduce inequality may generate substantial benefits beyond those normally considered (e.g. less government taxes being spent on unemployment benefits, health or on crime and protection). Thus, the current focus on Northern Australia provides policy and other decision-

5 See Ahmad \& Stern (1991), Auerbach \& Hines (2002). 
makers with a heady opportunity to identify development proposals that both increase incomes and reduce inequality by providing marginalised groups (Indigenous and otherwise) with opportunities to engage, financially, with large-scale projects. Not only will this serve a fairer pie to communities in the north, but it will serve a larger one.

\section{References}

ABC News. (2015, 17 November). Asian conglomerate Jemena wins tender to build NEGI gas pipeline from Northern Territory to Queensland. Retrieved from www.abc.net.au/news/2015-11-17/jemena-wins-negi-gas-pipeline-preferredbidder-in-nt/6947746

Acemoglu, D. \& Autor, D. H. (2010). Skills, tasks and technologies: Implications for employment and earnings (NBER Working Papers No. 16082). National Bureau of Economic Research.

Ahluwalia, M. S. (1976). Inequality, poverty and development. Journal of Development Economics, 3(4), 307-342.

Ahmad, E. \& Stern, N. (1991). The theory and practice of tax reform in developing countries. Cambridge, England: Cambridge University Press.

Altman, J. (2009). Beyond closing the gap: Valuing diversity in Indigenous Australia. (Centre for Aboriginal Economic Policy Research Working Paper No. 54). Canberra, ACT: ANU.

Altman, J., Biddle, N. \& Hunter, B. (2008). How realistic are the prospects for 'closing the gaps' in socioeconomic outcomes for Indigenous Australians? (Centre for Aboriginal Economic Policy Research Discussion Paper No. 287). Canberra, ACT: ANU.

Anand, S. \& Kanbur, S. M. R. (1993). Inequality and development: A critique. Journal of Development Economics, 41(1), 19-43.

Athanasopoulos, G. \& Vahid, F. (2003). Statistical inference and changes in income inequality in Australia. Economic Record, 79(247), 412-424.

Auerbach, A. J. \& Hines, J. R. (2002). Taxation and economic efficiency. In A. J. Auerbach \& M. Feldstein (Eds), Handbook of public economics (pp. 1347-1421). Elsevier.

Australian Government. (2015). Our north, our future: White paper on developing Northern Australia. Retrieved from www.industry.gov.au/data-and-publications/ our-north-our-future-white-paper-on-developing-northern-australia 
Australian Institute of Health and Welfare (AIHW). (2010). Australia's health 2010 (Australia's Health Series No. 12., Cat. No. AUS 122). Canberra, ACT: AIHW.

Bailey, M. J. \& Dynarski, S. M. (2011). Inequality in post-secondary education. In G. J. Duncan \& R. J. Murnane (Eds), Whither opportunity?: Rising inequality, schools, and children's life chances (pp. 117-132). Russell Sage Foundation.

Baum, S. (2006). A typology of socio-economic advantage and disadvantage in Australia's large non-metropolitan cities, towns and regions. Australian Geographer, 37, 233-258.

Biddle, N., Taylor, J. \& Yap, M. (2008). Indigenous participation in regional labour markets, 2001-06 (Centre for Aboriginal Economic Policy Research Discussion Paper No. 288). Canberra, ACT: ANU.

Blackwell, B., Fischer, A., McFarlane, J. \& Dollery, B. (2015). Mining and other industry contributions to employment leakage in Australia's Northern Territory. The Journal of Developing Areas, 49(6), 263-278.

Brokensha, H., Taylor, A. \& Carson, D. (2013). The Northern Territory's nonresident workforce: One census on (Northern Institute Research Brief Series, Issue No. 201304). Retrieved from www.cdu.edu.au/sites/default/files/ research-brief-2013-4.pdf

Brosnan, S. \& de Waal, F. B. M. (2003). Monkeys reject unequal pay. Nature, 425(6955), 297-299.

Brouwer, R., Akter, S., Brander, L. \& Haque, E. (2009). Economic valuation of flood risk exposure and reduction in a severely flood prone developing country. Environment and Development Economics, 14(03), 397-417.

Campano, F. \& Salvatore, D. (1988). Economic development, income inequality, and Kuznets' U-shaped hypothesis. Journal of Policy Modeling, 10(2), 265-280.

Campbell, R. (2015, 31 August). Fact check: Will Adani's coal mine really boost employment by 10,000 jobs? The Australian. Retrieved from www. businessspectator.com.au/article/2015/8/31/policy-politics/fact-check-willadanis-coal-mine-really-boost-employment-10000.

Carson, D., Taylor, A. \& Campbell, S. (2009). Demographic trends and likely futures for Australia's tropical rivers. Darwin, NT: Charles Darwin University.

Carson, D. B. \& Carson, D. A. (2014). Local economies of mobility in sparsely populated areas: Cases from Australia's spine. Journal of Rural Studies, 36, 340-349. 
Cheng, W. (2006). A new perspective on economic development and income inequality. Economic Papers, 25, 125-130.

Cohen, M. A. (2012). The costs of crime and justice. Routledge.

Daly, H. E. \& Farley, J. (2004). Ecological economics: Principles and applications. Washington, DC: Island Press.

Dawes, C. T., Fowler, J. H., Hohnson, T., McElreath, R. \& Smirnov, O. (2007). Egalitarian motives in humans. Nature, 446, 794-796.

Deininger, K. \& Squire, L. (1998). New ways of looking at old issues: Inequality and growth. Journal of Development Economics, 57(2), 259-287.

Detotto, C. \& Otranto, E. (2010). Does crime affect economic growth? Kyklos, 63(3), 330-345.

Doms, M. A., Lewis, E. \& Robb, A. (2010). Local labor force education, new business characteristics, and firm performance. Journal of Urban Economics, 67, $61-77$.

Duncan, G. J. \& Murnane, R. J. (2014). Growing income inequality threatens American education. Phi Delta Kappan, 95(6), 8-14.

Elgar, F. J., Pickett, K. E., Pickett, W., Craig, W., Molcho, M., Hurrelmann, K. \& Lenzi, M. (2013). School bullying, homicide and income inequality: A cross-national pooled time series analysis. International Journal of Public Health, 58, 237-245. doi.org/10.1007/s00038-012-0380-y

Ezcurra, R. \& Rodriguez-Pose, A. (2013). Does economic globalization affect regional inequality? A cross-country analysis. World Development, 52, 92-103. doi.org/10.1016/j.worlddev.2013.07.002

Faal, E. (2007). Growth, investment and productivity in Papua New Guinea. Pacific Economic Bulletin, 22(1), 16-38.

Fehr, E. \& Schmidt, K. M. (1999). A theory of fairness, competition, and cooperation. The Quarterly Journal of Economics, 114(3), 817-868.

Fryer, R. G. \& Loury, G. C. (2005). Affirmative action and its mythology. The Journal of Economic Perspectives, 19(3), 147-162.

Harrison, A., McLaren, J. \& McMillan, M. S. (2010). Recent findings on trade and inequality (NBER Working Papers, No. 16425). National Bureau of Economic Research. 
Hoeller, P., Joumard, I., Pisu, M. \& Bloch, D. (2012). Less income inequality and more growth - are they compatible?: Part 1. Mapping income inequality across the OECD (OECD Economics Department Working Paper No. 924). OECD Publishing. doi.org/10.1787/5k9h297wxbnr-en

Hunter, B. (1999). Three nations, not one: Indigenous and other Australian poverty. Canberra, ACT: Centre for Aboriginal Economic Policy Research.

Hunter, B. \& Gray, M. (1999). Income fluctuations over the lifecycle: A cohort analysis of Indigenous and non-Indigenous Australians, 1986-96. Canberra, ACT: Centre for Aboriginal Economic Policy Research.

Jaumotte, F., Lall, S. \& Papageorgiou, C. (2013). Rising income inequality: Technology, or trade and financial globalization? IMF Economic Review, 61, 271-309. doi.org/10.1057/imfer.2013.7

Koske, I., Fournier, J. \& Wanner, I. (2012). Less income inequality and more growth - are they compatible?: Part 2. The distribution of labour income (OECD Economics Department Working Paper No. 925). OECD Publishing. doi.org/ $10.1787 / 5 \mathrm{k} 9 \mathrm{~h} 2975$ rhhf-en

Kuznets, S. (1955). Economic growth and income inequality. The American Economic Review, 45(1), 1-30.

Leigh, A., Jencks, C. \& Smeeding, T. M. (2009). Health and economic inequality. In W. Salverda, B. Nolan \& T. Smeeding (Eds), The Oxford handbook of economic inequality. Oxford, England: Oxford University Press.

Liberal Party of Australia. (2013). The Coalition's 2030 vision for developing Northern Australia. Retrieved from parlinfo.aph.gov.au/parlInfo/search/display/display. w3p;query=Id\%3A\%22library\%2Fpartypol\%2F2550511\%22;src1 =sm 1

Papanek, G. \& Kyn, O. (1986). The effect on income distribution of development, the growth rate and economic strategy. Journal of Development Economics, 23(1), 55-65.

Pholi, K., Black, D. \& Richards, C. (2009). Is 'close the gap' a useful approach to improving the health and wellbeing of Indigenous Australians? Australian Review of Public Affairs, 9(2), 1-13.

Reeson, A. F., Measham, T. G. \& Hosking, K. (2012). Mining activity, income inequality and gender in regional Australia. Australian Journal of Agricultural and Resource Economics, 56, 302-313.

Rodriguez-Pose, A. (2012). Trade and regional inequality. Economic Geography, 88(2), 109-136. 
Rolfe, J., Lawrence, R., Gregg, D., Morrish, F. \& Ivanova, G. (2010). Impacts of the mining boom in the Bowen Basin 2004-2006. Australasian Journal of Regional Minerals and Energy Studies, 13, 134-153.

Rolfe, J., Miles, B., Lockie, S. \& Ivanova, G. (2007). Lessons from the social and economic resources sector in Queensland economic impact study. Brisbane, Qld: The Eidos Institute.

Shane, S. (2009). Why encouraging more people to become entrepreneurs is bad public policy. Small Business Economics, 33, 141-149.

Stoeckl, N. (2007). Using surveys of business expenditure to draw inferences about the size of regional multipliers: A case-study of tourism in Northern Australia. Regional Studies, 41(7), 917-931.

Stoeckl, N., Esparon, M., Stanley, O., Farr, M., Delisle, A. \& Altai, Z. (2013). The great asymmetric divide: An empirical investigation of the link between Indigenous and non-Indigenous economic systems in Northern Australia. Papers in Regional Science 93(4), 783-801. doi.org/10.1111/pirs.12028

Stoeckl, N., Jackson, S., Pantus, F., Finn, M., Kennard, M. \& Pusey, B. (2013). An integrated assessment of some of the financial, hydrological, ecological and social impacts of 'development' on Indigenous and non-Indigenous people in Northern Australia. Biological Conservation, 159, 214-221.

Stoeckl, N., Stanley, O., Brown, V. \& Stoeckl, W. (2007, October). Regionaleconomic multipliers in Australia's tropical savannas (TS CRC Project Report). Townsville, Qld: James Cook University. Retrieved from www.nintione.com.au/resources/ $\mathrm{rao} /$ regional-economic-multipliers-in-australias-tropical-savannas/

Tanton, R., Harding, A., Daly, A., McNamara, J. \& Yap, M. (2009). Australian children at risk of social exclusion: A spatial index for gauging relative disadvantage. Population, Space and Place, 16(2), 135-150.

Taylor, J. \& Hunter, B. (1998). The job still ahead: Economic costs of continuing Indigenous employment disparity. Canberra, ACT: Centre for Aboriginal Economic Policy Research.

Taylor, J. \& Stanley, O. (2005). The opportunity costs of the status quo in the Thamarrur Region (Centre for Aboriginal Economic Policy Research Working Paper No. 18). Canberra, ACT: ANU.

Taylor, A., Larson, S., Stoeckl, N. \& Carson, D. (2011). The haves and have nots in Australia's Tropical North-new perspectives on a persisting problem. Geographical Research, 49(1), 13-22. 
Watson, I. (2013). Bridges or traps? Casualisation and labour market transitions in Australia. Journal of Industrial Relations, 55(1), 6-37.

Wilkinson, R. (1996). Unhealthy societies: The afflictions of inequality. London, England: Routledge.

Wilkinson, R. \& Pickett, K. (2010). The spirit level: Why equality is better for everyone. Penguin Books Ltd.

Yang, X. \& Zhang, D. (2003). Economic development, international trade and income distribution: The perspective of the new growth theories. Journal of Economics, 78, 163-190. 
This text is taken from Leading from the North: Rethinking Northern Australia Development, edited by Ruth Wallace, Sharon Harwood, Rolf Gerritsen, Bruce Prideaux, Tom Brewer, Linda Rosenman and Allan Dale, published 2021 by ANU Press, The Australian National University, Canberra, Australia. 